\title{
Evaluasi Kinerja Organisasi Publik dengan Menggunakan Pendekatan Balanced Scorecard dan Analytic Network Process
}

\author{
Adi Mora Tunggul ${ }^{a^{*}}$, R. Rizal Isnanto ${ }^{b}$, Oky Dwi Nurhayati ${ }^{c}$ \\ ${ }^{a}$ Mahasiswa Magister Sistem Informasi, Universitas Diponegoro \\ ${ }^{\mathrm{b}}$ Fakultas Teknik, Universitas Diponegoro \\ ${ }^{\mathrm{c}}$ Fakultas Teknik, Universitas Diponegoro
}

Naskah Diterima : 21 April 2016; Diterima Publikasi : 11 Juli 2016

DOI: $10.21456 /$ vol6iss2pp124-132

\begin{abstract}
Strategic business management has an important role for the evaluation of performance in accordance with the vision and mission of the organization. Balanced Scorecard is a method that can be used for the analysis of organizational performance in the sector of financial and non-financial. The purpose of the research is to build information systems used to assess the performance of public services in a local government. The constructed information system used to facilitate the performance evaluation process. The method used is the Balanced Scorecard and Analytical Network. Balanced Scorecard approach is applied to determine the hierarchy of the financial perspective, customer perspective, internal business processes, and learning and growth perspective as well as their respective performance indicators for public services. While the Analytical Network Process approach used to tolerate uncertainty and ambiguity of information. The research results provides recommendations to the management of local government on strategies to improve the performance of public services.
\end{abstract}

Keywords: Information systems; performance of public services; balanced scorecard; analytic network process.

\begin{abstract}
Abstrak
Manajemen bisnis strategis mempunyai peranan penting untuk evaluasi kinerja sesuai dengan visi misi organisasi. Balanced scorecard merupakan metode yang dapat dipakai untuk analisis kinerja organisasi dalam sector keuangan dan non-keuangan. Tujuan dari penelitian ini adalah membangun sebuah model yang digunakan untuk menilai kinerja pelayanan publik dalam suatu pemerintahan daerah. Sistem informasi digunakan untuk memfasilitasi proses evaluasi kinerja.. Metode yang digunakan adalah Balanced Scorecard dan Analytical Network. Pendekatan Balanced Scorecard diterapkan untuk menentukan hirarki perspektif keuangan, perspektif pelanggan, perspektif proses bisnis internal, dan perspektif pembelajaran dan pertumbuhan serta masing-masing indikator kinerja untuk pelayanan publik. Sedangkan pendekatan Analytical Network Process digunakan untuk mentolerir ketidakjelasan dan ambiguitas informasi. Hasil penelitian ini memberikan rekomendasi kepada pihak manajemen pemerintahan daerah mengenai strategi dalam meningkatkan kinerja pelayanan publik.
\end{abstract}

Kata kunci: sistem informasi; kinerja pelayanan publik; balanced scorecard;analytic network process.

\section{Pendahuluan}

Saat ini organisasi publik menghadapi tantangan strategis yang cukup besar dan tekanan yang berat untuk menjadi lebih responsif terhadap tuntutan masyarakat dengan meningkatkan kualitas dan efisiensi. Situasi ini membuat sistem kontrol manajemen pemerintah tidak cukup untuk mencapai beberapa tujuan strategis, sehingga organisasi publik diminta untuk meningkatkan kinerja mereka secara efektif, inovatif dan efisien (Lupi et al., 2011). Sistem penilaian kinerja yang efisien dan akurat merupakan alat yang berguna yang memungkinkan manajemen dalam mengendalikan, memantau dan meningkatkan proses evaluasi kinerja. Karena itu, berbagai organisasi mencoba untuk membuat alat yang tepat dalam memenuhi tantangan ini dengan metode yang sesuai untuk evaluasi kinerja dan kualitas penilaian organisasi (Kadarova et al., 2014).

Penilaian kinerja dapat didefinisikan sebagai bagian dari proses pengelolaan yang diwujudkan secara berkala untuk menentukan keberhasilan atau kualitas dari proses atau kegiatan tertentu (Elbana, 2013). Telah dipahami bahwa penilaian kinerja organisasi merupakan salah satu fungsi manajemen, namun pada saat ini untuk melakukan penilaian

*) Penulis korespondensi: adimoratunggul@gmail.com 
kinerja organisasi sangatlah penting untuk menerapkan metode yang sesuai. Evaluasi kinerja adalah model penilaian untuk membandingkan rencana masa lalu dan eksekusi strategi, kegiatan operasi, pembentukan organisasi eksekutif dan partisipasi pegawai serta membantu organisasi dalam merencanakan masa depan strategi dan menyiapkan target kinerja pegawai untuk mencapai target akhir organisasi (Dreveton, 2013).

Evaluasi kinerja menjadi bagian dari manajemen dan sistem kontrol yang membantu organisasi untuk secara efektif mengelola sumber daya dalam kaitannya dengan tujuan organisasi (Wu dan Hung, 2008). Dalam evaluasi kinerja penilaian terhadap organisasi sangat penting untuk memahami bagaimana manajemen berkontribusi terhadap tujuan dan strategi organisasi. Banyak teknik serta metode pengendalian strategis yang bertujuan untuk mengevaluasi kinerja manajemen strategis organisasi bisnis maupun publik, salah satu metode manajemen sistem berkala dan sistematis adalah Balanced Scorecard (Leung et al., 2006).

Balanced Scorecard merupakan perencanaan strategis dan sistem manajemen yang digunakan secara luas dalam bisnis, industri, pemerintah, dan organisasi nirlaba di seluruh dunia untuk menyelaraskan kegiatan usaha dengan visi dan strategi organisasi yang dapat meningkatkan komunikasi internal dan eksternal serta memantau kinerja organisasi terhadap tujuan strategis organisasi (Grigoroudis et al., 2012). Konsep Balanced Scorecard menyediakan kerangka kerja yang tidak hanya memberikan evaluasi kinerja, tetapi juga membantu mengidentifikasi apa yang harus dilakukan dan dinilai, sehingga memungkinkan para eksekutif untuk mengeksekusi manajemen strategi yang telah diterapkan (Banker dkk., 2004). Namun dalam penerapannya model teknik pengendalian strategis dengan pendekatan Balanced Scorecard memiliki beberapa kekurangan secara metodologis seperti pentingnya bobot relatif atau pentingnya evaluasi indikator-indikator kinerja pada setiap perspektif (Yuksel dan Dagdeviren, 2010).

Untuk memperbaiki penerapan Balanced Scorecard dalam berbagai indikator kinerja, telah diterapkan teknik Analytic Network Process dalam memfasilitasi model pelaksanaan teknik serta menentukan bobot relatif antar perspektif Balanced Scorecard dan masing-masing indikator kinerja (Ravi et al., 2005). Analytic Network Process dikembangkan oleh Thomas Saaty sebagai sebuah pendekatan umpan balik untuk menggantikan proses hierarki dengan proses jaringan yang berhubungan antar tingkat. Analytic Network Process memberikan permodelan struktur dan sebuah proses yang memandu pengambil keputusan dalam menimbang berbagai kriteria dan memilih tindakan yang dimaksud untuk mencapai tujuan yang ingin ditetapkan (Tjader et al., 2014).
Menggabungkan pendekatan Balanced Scorecard dan Analytic Network Process telh adigunakan untuk membangun model pengambilan keputusan dalam menentukan strategi perusahaan teknologi informasi (Tjader et al., 2014). Memanfaatkan Balanced Scorecard dalam mengidentifikasi faktor-faktor yang mempengaruhi industri hotel dan apartement di Teheran dan kemudian diprioritaskan dengan teknik Analytic Network Process (Toosi dan Tabari, 2014). Serta mengembangkan metodologi Balanced scorecard untuk mengidentifikasi, mengukur dan mengelola pencapaian tujuan strategis organisasi serta menerapkan Analytic Network Process sebagai alat yang berguna untuk representasi kedua hubungan antara intangible assets (IAs) dan intellectual capital (IC) (Boj et al., 2014). Sistem penilaian juga dikembangkan berdasarkan kombinasi Balanced Scorecard dan Analytic Network Process untuk mentolerir ketidakjelasan dan ambiguitas informasi serta mengembangkan analisis struktur dalam penyelesaian masalah (Rabbani et al., 2014).

Penelitian ini bertujuan untuk desain model penilaian kinerja pelayan publik pada Pemerintahan daerah dengan menggunakan metode Balanced Scorecard dan Analytic Network Process. Kebaruan dari penelitian ini berkaitan dengan penerapan model terpadu dalam mengevaluasi kinerja pelayanan publik pada sebuah kantor pelayanan pajak di Semarang yang mencakup indikator-indikator sasaran strategis.

\section{Kerangka Teori}

\subsection{Balanced Scorecard}

Balanced Scorecard merupakan sebuah metodologi yang telah mencapai publikasi luas di kalangan ilmuwan dan manajer serta telah diterima secara luas karena mengisi kesenjangan antara pengembangan strategi dan realisasi dengan mendukung dan menghubungkan proses strategi manajemen (Viglas, 2011). Balanced Scorecard juga mencerminkan keseimbangan antara tujuan jangka pendek dan jangka panjang, langkah-langkah keuangan dan bukan keuangan, langkah-langkah eksternal dan internal serta indikator kinerja serta memberikan penekanan sebuah ukuran inisiatifinisiatif strategis, dan konsep hubungan strategis antara tujuan dan strategi bisnis.

Untuk menerapkan kerangka Balanced Scorecard, seorang manajer perlu untuk membangun kekuatan dari semua hubungan yang saling berpengaruh dalam menentukan kepentingan relatif dari masing-masing unit organisasi (Tjader 2014). Sebagai alat manajemen strategis, Balanced Scorecard memfasilitasi penjabaran visi dan tujuan organisasi ke dalam langkah-langkah operasional dan target serta inisiatif (Lupi et al., 2011).

Dalam berbagai hal Balanced Scorecard telah diterapkan untuk proses dan dampak manajemen strategis: Bukti dari sektor publik di Uni Emirat Arab 
(Elbanna, 2013). Serta keuntungan dari penerapan Balanced Scorecard dalam organisasi sektor publik di Prancis yang melampaui pengukuran kinerja strategis, organisasi, manusia dan manfaat yang diperoleh (Dreveton, 2013).

\subsection{Analytical Network Process}

Teknik Analytical Network Process menggunakan hubungan hierarki searah untuk model tingkat dalam pengambilan keputusan. Analytical Network Process memungkinkan untuk interaksi yang kompleks antara berbagai komponen dari masalah keputusan sehingga menjadi pilihan yang lebih baik untuk mempelajari masalah pengambilan keputusan yang lebih kompleks, serta membawa semua tujuan keputusan, kriteria, alternatif dan pengambil keputusan atau pemangku kepentingan ke dalam kerangka terpadu tunggal dan memfasilitasi interaksi dan umpan balik dari elemen alternatif, kriteria dan subkriteria dalam kelompok serta antara kelompok (Saaty dan Vargas, 2006).

Analytical Network Process dapat digunakan dalam berbagai penerapan proses pengambilan keputusan yang memungkinkan penilaian subjektif selain untuk informasi kuantitatif juga dapat digunakan ke dalam proses evaluasi (Shang dkk., 2004). Kebanyakan masalah pengambilan keputusan yang kompleks memiliki banyak elemen saling bergantung yang bisa dilakukan dan diproses dengan memanfaatkan umpan balik atau kemampuan interaksi model Analytical Network Process (Saaty dan Vargas, 2006). Dalam berbagai hal, Analytical Network Process telah diterapkan untuk mendukung pengambil keputusan dalam pemilihan supplier: Sebuah studi kasus di sebuah perusahaan elektronik (Gencer dan Gurpinar, 2007) serta memilih dan benchmarking sistem Enterprise resource planning (ERP) (Perçin, 2008).

\section{Metodologi}

Dalam penelitian ini, penerapan evaluasi kinerja dengan menggunakan pendekatan Balanced Scorecard dan Analytical Network Process dilakukan pada sector pelayanan publik dalam bidang pajak pada Pemerintah Daerah Kota Semarang. Proses penerapan penilaian evaluasi kinerja dirancang dengan menggunakan format kuesioner Analytical Network Process dan masukan dianalisis melalui sebuah program aplikasi sistem informasi evaluasi kinerja yang dibangun untuk mendapatkan kepentingan relatif dari perspektif dan masing-masing indikator kinerja. Prosedur penelitian model Balanced Scorecard dan Analytical Network Process yang diusulkan, disusun dalam sebuah kerangka penelitian melalui tahapan, seperti yang ditunjukkan pada Gambar 1 .

Model penelitian yang disusulkan terdiri dari tahapan: 1) Peryataan visi organisasi yang menjelaskan misi dan strategi bisnis yang akan ditempuh untuk mencapai tujuan organisasi serta merumuskan sasaran strategis yang dijabarkan dalam rencana strategis organisasi, 2) Penentuan perspektif Balanced Scorecard dan indikator-indikator kinerja yang diperoleh dengan menyiapkan daftar evaluasi kinerja, kemudian melakukan wawancara dengan pihak manajemen untuk mendapatkan data sasaran strategis organisasi sebagai bahan penilaian evaluasi kinerja, 3) Melakukan proses pembentukan struktur hierarki pengambilan keputusan model Analytical Network Process pada perspektif dan masing-masing indikator menjadi hierarki kriteria dan subkriteria yang akan menjadi penilaian evaluasi, kemudian dilakukan proses perhitungan nilai bobot dan proses normaliasi matriks perbandingan berpasangan serta menghitung nilai eigen untuk menguji konsistensi antar masing-masing kriteria dan untuk mengukur bobot menggunakan prosedur random indeks seperti pada Tabel 3, 4) Menghitung bobot lokal dari masingmasing perspektif dan indikator-indikator kinerja serta menghitung nilai eigen untuk masing-masing kriteria dan subkriteria yang akan digunakan untuk proses perhitungan supermatriks, 5) Menghitung supermatriks terbobot, supermatriks tidak terbobot dan supermatriks terbatas dalam ketergantungan antara perspektif dan indikator kinerja dalam matriks, 6) Menghitungan bobot global indikator-indikator kinerja dari masing-masing kriteria dan subkriteria proses perhitungan matriks perbandingan berpasangan yang menjadi dasar dalam proses evaluasi kinerja dan menampilkan hasil perhitungan kinerja organisasi publik.

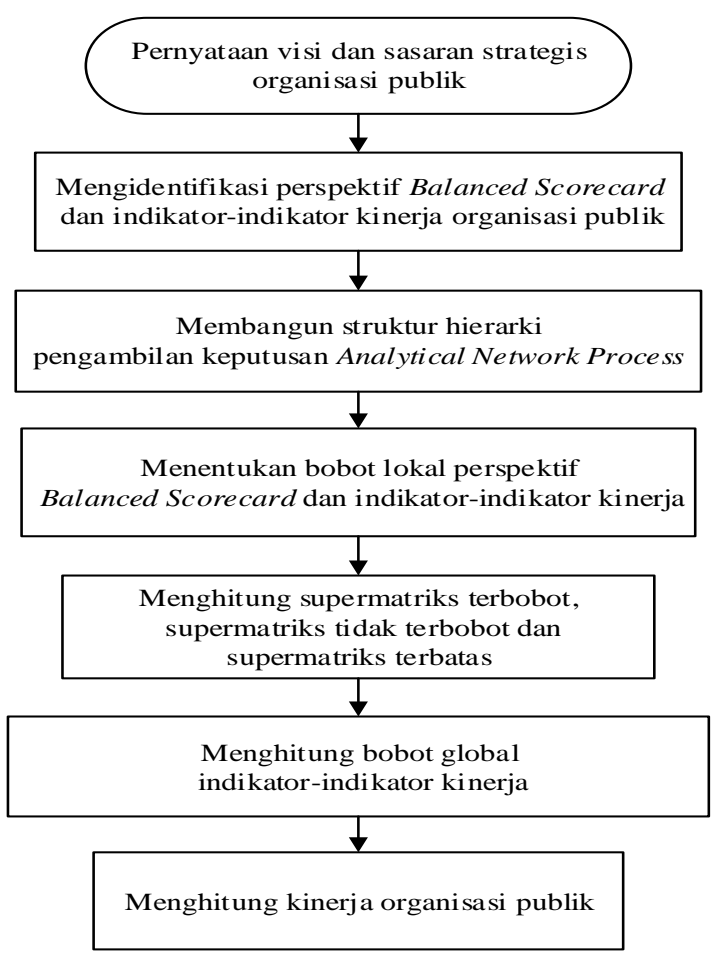

Gambar 1. Prosedur penelitian penilaian pelayanan publik 


\subsection{Pengumpulan Data}

Pengumpulan data menggunakan literatur Balanced Scorecard mengenai evaluasi kinerja pada organisasi publik serta hasil proses wawancara dengan pakar atau pihak manajemen mengenai evaluasi kinerja, dari hasil tersebut kemudian dirumuskan berdasarkan hierarki perspektif Balanced Scorecard yaitu perspektif keuangan, perspektif pelanggan, perspektif proses bisnis internal dan perspektif pembelajaran dan pertumbuhan. Kuesioner dirancang dengan format Analytical Network Process (perbandingan berpasangan skala 9 poin) dan kuesioner perbandingan berpasangan dibagikan kepada pegawai negeri sipil untuk dapat memberikan penilaian.

Hierarki evaluasi kinerja merupakan data sasaran strategis yang diperoleh dari penjabaran visi dan tujuan organisasi yang merupakan sesuatu yang akan dicapai atau dihasilkan pada kurun waktu tertentu, serta menggambarkan arah strategik organisasi, perbaikan-perbaikan yang ingin diciptakan sesuai dengan tugas dan fungsi masing-masing unit, serta meletakkan kerangka prioritas untuk memfokuskan program dan kegiatan yang akan dilaksanakan. Hirarki evaluasi kinerja dijabarkan seperti pada Tabel 1 .

Tabel 1. Hierarki evaluasi kinerja

\begin{tabular}{|c|c|c|}
\hline Tujuan & Perspektif & Indikator Kinerja \\
\hline \multirow[t]{13}{*}{$\begin{array}{l}\text { Evaluasi } \\
\text { Kinerja }\end{array}$} & \multirow[t]{2}{*}{$\begin{array}{l}\text { Perspektif } \\
\text { Keuangan }\end{array}$} & $\begin{array}{l}\text { Pertumbuhan ekonomi yang } \\
\text { inklusif }\end{array}$ \\
\hline & & $\begin{array}{l}\text { Pengelolaan neraca } \\
\text { pemerintahan yang optimal }\end{array}$ \\
\hline & Perspektif & Pemenuhan layanan public \\
\hline & Pelanggan & $\begin{array}{l}\text { Kepatuhan pengguna layanan } \\
\text { yang tinggi }\end{array}$ \\
\hline & \multirow{4}{*}{$\begin{array}{l}\text { Perspektif } \\
\text { Proses Bisnis } \\
\text { Internal }\end{array}$} & $\begin{array}{l}\text { Formulasi kebijakan fiskal } \\
\text { yang berkualitas }\end{array}$ \\
\hline & & $\begin{array}{l}\text { Belanja dan transfer yang } \\
\text { optimal }\end{array}$ \\
\hline & & $\begin{array}{l}\text { Pengelolaan aset dan } \\
\text { pembiayaan yang optimal }\end{array}$ \\
\hline & & Penegakan hukum yang efektif \\
\hline & \multirow{5}{*}{$\begin{array}{l}\text { Perspektif } \\
\text { Pembelajara } \\
\text { n dan } \\
\text { Pertumbuhan }\end{array}$} & Sumber daya manusia yang \\
\hline & & kompetitif \\
\hline & & Organisasi yang kondusif \\
\hline & & $\begin{array}{l}\text { Sistem informasi manajemen } \\
\text { yang terintegrasi }\end{array}$ \\
\hline & & $\begin{array}{l}\text { Pelaksanaan anggaran yang } \\
\text { optimal }\end{array}$ \\
\hline
\end{tabular}

\subsection{Pengolahan Data}

Pengolahan data dilakukan mengikuti tahapan pada metode Analytical Network Process yaitu dengan menetapkan sasaran strategi yang akan menjadi kriteria dan subkriteria dalam pembobotan. Analytical Network Process digunakan untuk menghasilkan bobot empat perspektif dan dua belas indikator dari Balanced Scorecard.

Proses dimulai dengan membangun struktur hierarki pengambilan keputusan kriteria dan subkriteria dimana setiap pegawai negeri sipil dimasing-masing unit diminta untuk memberikan penilaian dengan mengekspresikan tingkat kepentingan relatif dari dua elemen baik kriteria maupun subkriteria, serta nilai numerik pada seluruh perbandingan berpasangan diperoleh dari perbandingan berpasangan yang telah ditetapkan, seperti pada Tabel 2 (Saaty dan Vargas., 2006)

Tabel 2. Skala perbandingan berpasangan

\begin{tabular}{|c|c|c|}
\hline $\begin{array}{c}\text { Tingkat } \\
\text { kepentingan }\end{array}$ & Definisi & Keterangan \\
\hline 1 & Sama penting & $\begin{array}{l}\text { Elemen } 1 \text { dan elemen } 2 \\
\text { sama pentingnya }\end{array}$ \\
\hline 3 & $\begin{array}{l}\text { Sedikit lebih } \\
\text { penting }\end{array}$ & $\begin{array}{l}\text { Elemen } 1 \text { sedikit lebih } \\
\text { penting dibanding elemen } 2\end{array}$ \\
\hline 5 & $\begin{array}{l}\text { Cukup } \\
\text { penting }\end{array}$ & $\begin{array}{l}\text { Elemen } 1 \text { lebih penting } \\
\text { dibanding elemen } 2\end{array}$ \\
\hline 7 & $\begin{array}{l}\text { Sangat } \\
\text { penting }\end{array}$ & $\begin{array}{l}\text { Elemen } 1 \text { sangat penting } \\
\text { dibanding elemen } 2\end{array}$ \\
\hline 9 & $\begin{array}{l}\text { Mutlak lebih } \\
\text { penting }\end{array}$ & $\begin{array}{l}\text { Elemen } 1 \text { mutlak lebih } \\
\text { penting dibanding elemen } 2\end{array}$ \\
\hline $2,4,6,8$ & $\begin{array}{l}\text { Nilai-nilai di } \\
\text { antara dua } \\
\text { pertimbangan } \\
\text { yang } \\
\text { berdekatan }\end{array}$ & $\begin{array}{l}\text { Nilai ini diberikan bila ada } \\
\text { dua komponen di antara } \\
\text { dua pilihan }\end{array}$ \\
\hline $\begin{array}{l}\text { Resiprokal } \\
\text { (Kebalikan) }\end{array}$ & \multicolumn{2}{|c|}{$\begin{array}{l}\text { Jika untuk aktivitas ke-i mendapat satu angka } \\
\text { bila dibandingkan dengan aktivitas ke-j, } \\
\text { maka j mempunyai nilai kebalikannya } \\
\text { dibandingan dengan } \mathrm{i} \text {. }\end{array}$} \\
\hline
\end{tabular}

Selanjutnya menganalisis konsistensi prioritas pada normaliasasi matriks untuk mendapatkan perhitungan nilai eigen dan vektor eigen seperti persamaan 1 (Saaty dan Vargas., 2006).

A. $w=\lambda_{\text {maks }} \cdot w$

Dalam Persamaan (1), $w$ merupakan vektor eigen, dan $\lambda_{\text {maks }}$ adalah nilai eigen terbesar dari matriks. Hasil nilai konsistensi matriks perbandingan berpasangan diperiksa untuk memastikan sebuah hasil penilaian yang konsisten dengan persamaan Consistency Index (CI) pada Persamaan (2) (Saaty dan Vargas., 2006).

$$
C I=\frac{\lambda_{m a k s}-n}{n-1}
$$

Dimana $\lambda_{\text {maks }}$ merupakan nilai rata-rata keseluruhan kriteria dan $n$ adalah jumlah matriks perbandingan kriteria serta selain itu, Consistency Rasio (CR) dijelaskan pada Persamaan (3) (Saaty dan Vargas., 2006).

$$
C R=\frac{C I}{I R}
$$

Dimana $I R$ adalah Indeks random yang merupakan aturan nilai matriks yang yang telah ditentukan untuk mengukur konsistensi dari hasil perhitungan CR, jika nilai tidak konsisten maka perlu dilakukan perhitungan ulang dan jika nilai dinyatakan konsisten maka dapat dilanjutkan untuk proses perhitungan supermatriks dengan detail struktur jaringan terdiri 
dari hierarki yang merupakan bentuk umum dari supermatriks. Indeks random ditunjukkan pada Tabel 3, dimana $\mathrm{N}$ adalah ukuran matriks dan IR adalah indeks random.

Tabel 3. Indeks Random (Saaty dan Vargas., 2006)

\begin{tabular}{ccccccccc}
\hline $\mathrm{N}$ & 3 & 4 & 5 & 6 & 7 & 8 & 9 & 10 \\
\hline $\mathrm{IR}$ & 0.58 & 0.90 & 1.12 & 1.24 & 1.32 & 1.41 & 1.45 & 1.49
\end{tabular}

Proses perhitungan supermatriks tidak tertimbang dengan detail struktur jaringan terdiri dari hierarki yang merupakan bentuk umum dari supermatriks dimana $W_{i j}$ menunjukkan pengaruh setiap elemen dari hierarki i di hierarki j, yang disebut blok supermatriks, seperti ditunjukkan pada persamaan 4 (Zhang dan Wang., 2011).

$$
W_{i j}=\left[\begin{array}{cccc}
W_{i 1 j 1} & W_{i 1 j 2} & \ldots & W_{i 1 j_{n j}} \\
W_{i 2 j 2} & W_{i 2 j 2} & \ldots & W_{i 2 j_{n j}} \\
\vdots & \vdots & \vdots & \vdots \\
W_{i_{m 1} j 1} & W_{i_{m 2} j 1} & \cdots & W_{i_{m 1} j_{n j}}
\end{array}\right]
$$

Prioritas elemen dalam satu hierarki menurut kriteria tertentu dapat dilambangkan dengan supermatriks, yang berarti setiap kolom setiap hierarki dalam supermatriks adalah kolom stochastic. Supermatriks tertimbang mengenai setiap hierarki sebagai elemen dan perbandingan berpasangan menurut hierarki tertentu, Dimana $a_{i j}$ adalah pengaruh bobot hierarki $i$ dari hierarki $j$ dan $\bar{w}$ adalah supermatriks tertimbang. Hal ini penting untuk mempertimbangkan pengaruh antara setiap hierarki, seperti ditunjukkan pada Persamaan 5 (Zhang dan Wang, 2011).

$$
\bar{w} i j=a_{i j} W_{i j}
$$

Untuk mendapatkan supermatriks terbatas, supermatriks tertimbang dinaikkan nilanya untuk mendapatkan bobot global atau disebut vektor prioritas serta mendapatkan hasil perangkingan dengan memecahkan $\bar{w}^{\infty}$, seperti ditunjukkan pada Persamaan 6 (Zhang dan Wang, 2011).

$$
\bar{w}^{\infty}=\lim _{k \rightarrow \infty} \bar{w}^{k}
$$

\section{Hasil dan pembahasan}

Hasil penelitian ini berupa aplikasi sistem evaluasi kinerja organisasi publik yang menyajikan informasi tentang penilaian bobot kriteria dari perspektif keuangan, perspektif pelanggan, perspektif proses bisnis internal dan perspektif pembelajaran dan pertumbuhan, sehingga dapat diketahui nilai kriteria mana dari hasil pembobotan tersebut yang dapat menjadi acuan untuk evaluasi kinerja serta mengusulkan model penilaian kinerja untuk memberikan rekomendasi kepada pihak manajemen dalam mengevaluasi kinerja organisasi publik.

Sistem yang dirancang adalah sebuah sistem pengambilan keputusan yang mampu mengevaluasi kinerja organisasi berdasarkan penerapan Balanced Scorecard dan Analytical Network Process. Kerangka sistem informasi evaluasi kinerja ditunjukkan pada Gambar 2.

Kerangka sistem informasi pada penelitian ini berisi masukan data yang digunakan sebagai data analisa. Data masukan merupakan data kriteria dan subkriteria yaitu variabel yang digunakan dalam perhitungan bobot prioritas. Pada proses pengolahan data, masukan yang didapatkan dari kuesioner perbandingan berpasangan antar kriteria dan subkriteria berdasarkan perspektif Balanced Scorecard kemudian dianalisa dan dilakukan perhitungan dengan menggunakan model Analytical Network Process untuk penentuan bobot sasaran strategis dan perhitungan supermatriks untuk menghasilkan bobot prioritas dari kriteria dan subkriteria yang menjadi acuan evaluasi kinerja. Hasil dari pembobotan dengan Analytical Network Process berisi hasil perangkingan prioritas evaluasi kinerja yang ditampilkan dalam bentuk grafik yang memberikan informasi bobot sasaran strategis masing-masing perspektif Balanced Scorecard pada organisasi publik.

Penerapan aplikasi evaluasi kinerja pada organisasi publik dibangun dengan memanfaatkan pemrograman berorientasi objek yang dikelola oleh administrator dalam manajemen kuesioner, manajemen konten dan pengolahan data. Proses penilaian evaluasi kinerja organisasi publik dimulai dengan membuat daftar kriteria dan subkriteria yang diusulkan dan dibuat dalam kuesioner evaluasi kinerja dengan format Analytical Network Process (perbandingan berpasangan skala 9 poin) dan kuesioner perbandingan berpasangan dibagikan kepada pegawai negeri sipil untuk dapat memberikan penilaian dengan memilih tingkat kepentingan. Empat perspektif Balanced Scorecard digunakan sebagai kriteria dan indikator kinerja di setiap perspektif digunakan sebagai rincian subkriteria.

Pembobotan dari proses pengisian kuesioner dapat secara otomatis menghasilkan tampilan perhitungan matriks perbandingan berpasangan dengan menghitung nilai normalisasinya dengan cara membagi masing-masing angka pada setiap kolom dengan jumlah kolom masing-masing dan dilanjutkan dengan menghitung nilai rata-rata dari masing-masing baris dan nilai eigen yang didapat dari hasil setiap elemen kemudian dibagi jumlah dari keseluruhan hasil matriks perbandingan berpasangan. Tahapan menghitung bobot masing-masing kriteria dan subkriteria digabungkan untuk mendapatkan hasil perhitungan supermatriks melalui literasi dengan memasukkan semua nilai eigen kriteria dan subkriteria 
kedalam kolom supermatriks lalu diperoleh nilai bobot kriteria dan subkriteria secara keseluruhan.

Dalam penelitian ini data dikumpulkan dari kuesioner sebagai masukan untuk sistem evaluasi kinerja dan hasilnya dianalisis dengan menggunakan teknik Analytical Network Process. Kemudian aplikasi evaluasi kinerja pada organisasi publik dibangun dengan memanfaatkan pemrograman PHP dan basis data MySQL. Proses penilaian evaluasi kinerja organisasi publik dimulai dengan membuat daftar kriteria dan subkriteria yang diusulkan dan dibuat dalam kuesioner evaluasi kinerja seperti ditunjukkan pada Tabel 1. Empat perspektif Balanced Scorecard digunakan sebagai kriteria dan indikator kinerja di setiap perspektif digunakan sebagai rincian subkriteria untuk penilaian. Setiap pengambil keputusan diminta untuk mengisi kuesioner perbandingan berpasangan dengan memilih tingkat kepentingan pada skala sembilan poin tabel perbandingan berpasangan seperti yang ditunjukkan pada Gambar 3.

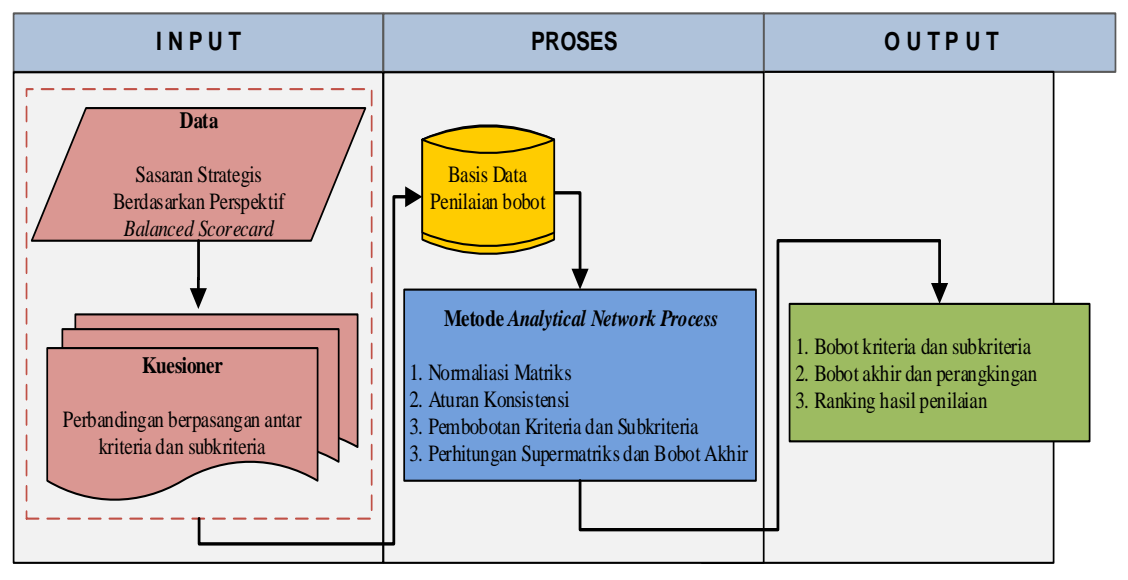

Gambar 2. Kerangka sistem informasi evaluasi kinerja

\begin{tabular}{|c|c|c|}
\hline \multicolumn{3}{|c|}{ Header } \\
\hline \multicolumn{3}{|c|}{ Perbandingan Berpasangan Antar Kriteria } \\
\hline Kriteria & Pilih Nilai & Kriteria \\
\hline Perspektif Pelanggan & 98765432123456789 & Perspektif Keuangan \\
\hline Perspektif Pelanggan & 98765432123456789 & Perspektif Proses Bisnis Internal \\
\hline Perspektif Pelanggan & 98765432123456789 & Perspektif Pembelajaran dan Pertumbuhan \\
\hline Perspektif Keuangan & 98765432123456789 & Perspektif Proses Bisnis Internal \\
\hline Perspektif Keuangan & 98765432123456789 & Perspektif Pembelajaran dan Pertumbuhan \\
\hline Perspektif Proses Bisnis Internal & 98765432123456789 & Perspektif Pembelajaran dan Pertumbuhan \\
\hline & Footer & \\
\hline
\end{tabular}

Gambar 3. Menu kuesioner perbandingan berpasangan

Setelah dilakukan pengisian kuesioner, sistem dapat secara otomatis menghasilkan tampilan perhitungan matriks perbandingan berpasangan dengan menghitung nilai normalisasinya dengan cara membagi masing-masing angka pada setiap kolom dengan jumlah kolom masing-masing dan dilanjutkan dengan menghitung nilai rata-rata dari masing-masing baris dan nilai eigen yang didapat dari hasil setiap elemen kemudian dibagi jumlah dari keseluruhan hasil matriks perbandingan berpasangan. Nilai konsistensi diperoleh dengan mengkalikan setiap nilai pada kolom pertama dengan prioritas relatif elemen pertama, nilai pada kolom kedua dengan prioritas relatif elemen kedua, dan seterusnya kemudian menjumlahkan setiap baris matriks perbandingan berpasangan dimana dengan nilai $C R$ lebih kecil dari 0,10 maka ketidakkonsistenan pendapat dari pembuat keputusan masih dapat diterima jika tidak maka perlu dilakukan penilaian ulang seperti yang ditunjukkan pada Gambar 6. Tahapan menghitung bobot masing-masing kriteria dan subkriteria digabungkan untuk mendapatkan hasil perhitungan supermatriks melalui iterasi dengan 
memasukkan semua nilai eigen kriteria dan subkriteria kedalam kolom supermatriks lalu diperoleh nilai bobot kriteria dan subkriteria secara keseluruhan.

Pada tahap ini diformulasikan hubungan antar kriteria untuk menentukan matriks perbandingan berpasangan. Perbandingan berpasangan dilakukan dengan mengacu ke semua kriteria yang mempunyai pengaruh terhadap kriteria lain. Tabel 4.1 menunjukkan matriks perbandingan hasil kriteria keuangan.

Tabel 4. Matriks perbandingan hasil kriteria keuangan

\begin{tabular}{lcccc}
\hline Kriteria & K1 & K2 & K3 & K4 \\
\hline K1 & 1 & 3 & 3 & 5 \\
K2 & $1 / 3$ & 1 & $1 / 3$ & $1 / 5$ \\
K3 & $1 / 3$ & 2 & 1 & $1 / 5$ \\
K4 & $1 / 2$ & 2 & 2 & 1 \\
\hline
\end{tabular}

Hasil kriteria keuangan (K1) 3 lebih penting dari kriteria pelanggan (K2), 3 lebih penting dari kriteria proses bisnis internal (K3) dan 5 cukup penting dibandingkan dengan kriteria pembelajaran dan pertumbuhan (K4). Dari hasil penjumlahan matriks perbandingan berpasangan selanjutnya dihitung matriks normalisasinya dengan cara membagi masingmasing angka pada setiap kolom dengan jumlah kolom masing-masing dan dilanjutkan dengan menghitung nilai rata-rata dari masing-masing baris. Setelah dihitung matriks normalisasi setiap perspektif kemudian dilakukan perhitungan konsistensi dengan mengkuadratkan matriks perbandingan berpasangan, perkalian antara baris dengan kolom matriks berpasangan. Dari hasil kuadrat matriks perbandingan berpasangan kemudian dijumlahkan untuk mendapatkan nilai perhitungan eigenvector kriteria keuangan. Hasil penjumlahan setiap baris matriks dan menghitung nilai eigenvector yang didapat dari hasil setiap elemen kemudian dibagi jumlah dari keseluruhan hasil matriks perbandingan berpasangan. Tabel 5. menunjukkan perhitungan matriks nilai eigenvector kriteria keuangan.

Tabel 5. Matriks nilai eigenvector kriteria keuangan

\begin{tabular}{cccc}
\hline Kriteria & Hasil Baris & Jumlah Baris & Nilai eigen \\
\hline Baris K1 & 12.000 & 23.360 & 0,522 \\
Baris K2 & 2.330 & 23.360 & 0,113 \\
Baris K3 & 3.830 & 23.360 & 0,163 \\
Baris K4 & 5.200 & 23.360 & 0,202 \\
\hline
\end{tabular}

Tabel 6. Penjumlahan eigenvector kriteria

\begin{tabular}{lc}
\multicolumn{2}{c}{ Keuangan } \\
\hline Kriteria & Hasil Baris \\
\hline Baris K1 & $(0,5522 \times 1)+(0,1113 \times 3)$ \\
& $+(0,163+3)+(0,202 \times 5)=2,3606$ \\
Baris K2 & $(0,5522 \times 0.3)+(0,1113 \times 1)$ \\
\hline
\end{tabular}

\begin{tabular}{cc}
\hline & $+(0,163+0.5)+(0,202 \times 0.5)=0,4696$ \\
Baris K3 & $(0,5522 \times 0.3)+(0,1113 \times 2)$ \\
& $+(0,163+1)+(0,202 \times 0.5)=0,6643$ \\
Baris K4 & $(0,5522 \times 0.2)+(0,1113 \times 2)$ \\
& $+(0,163+2)+(0,202 \times 1)=0,8591$ \\
\hline
\end{tabular}

Dalam pembuatan keputusan, penting untuk mengetahui seberapa baik konsistensi yang dengan mengkalikan setiap nilai pada kolom pertama dengan prioritas relatif elemen pertama, nilai pada kolom kedua dengan prioritas relatif elemen kedua, dan seterusnya kemudian menjumlahkan setiap baris. Tabel 6.menunjukkan hasil dari penjumlahan baris dibagi dengan nilai eigenvector kriteria keuangan. Dengan menjumlahkan hasil bagi dengan banyaknya elemen yang ada dan hasilnya disebut $\lambda$ maks, perhitungan dengan menggunakan persamaan (1)

$\lambda_{\text {maks }}=\frac{4,521072+\cdots+4,252970}{4}=4,2516$

Indeks konsistensi ${ }^{4}(C I)$ dihitung dengan menggunakan persamaan (2)

$C I=\frac{\lambda \text { maks }-\mathrm{n}}{n-1}=\frac{4.251601-4}{4-1}=0,083$

Rasio Konsistensi $(C R)$ dihitung dengan menggunakan Persamaan (3).

$$
C R=\frac{C I}{I R}=\frac{0,083}{0,90}=0,092
$$

Karena jumlah kriteria adalah 4 , maka indeks Rasio = 0,90. Nilai 0,092 menunjukkan konsistensi karena lebih kecil dari nilai rasio konsistensi.

Dengan cara yang sama diperoleh penilaian hasil ktiteria pelangan dengan cara penjumlahan setiap baris matriks dan menghitung nilai eigenvector yang didapat dari hasil setiap elemen kemudian dibagi jumlah dari keseluruhan hasil matriks perbandingan berpasangan, dengan $. \lambda_{\text {maks }}=4,0327, \quad$ Rasio Konsistensi $C R=0,0121$. Jumlah kriteria $=4$, dengan Indeks Rasio $=0,90$. Nilai 0,0121 menunjukkan konsistensi karena lebih kecil dari nilai rasio konsistensi.

Untuk penilaian hasil ktiteria proses bisnis internal diperoleh $\lambda_{\text {maks }}=4,1157$, dengan Rasio Konsistensi $C R=0,0429$. Karena jumlah kriteria $=4$, maka Indeks Rasio $=0,9$, dan dengan nilai 0,0429 menunjukkan konsistensi karena lebih kecil dari nilai rasio konsistensi. Untuk penelianan hasi untuk pembelajaran dan pertumbuhan, diperoleh $\lambda_{\text {maks }}=$ 4,1898 dengan Rasio Konsistensi CR + 0,0703. Dengan jumlah kriteria $=4$, maka Indeks Rasio $=0,9$, dan dengan nilai 0,0703 menunjukkan konsistensi karena lebih kecil dari nilai rasio konsistensi.

Berdasarkan hasil penelitian diatas dapat diketahui bahwa penilaian matriks perbandingan pada keseluruhan kriteria telah dihitung menggunakan metode Analytic Network Process. Semua kriteria dinyatakan konsisten dan jika tidak konsisten maka data akan diulang lagi sampai konsisten, selanjutnya 
hasil nilai eigenvector kriteria digunakan untuk perhitungan penentuan bobot prioritas yang terbaik.

Berdasarkan input hail penilaian, , kriteria proses bisnis internal dengan bobot prioritas 0,34812 adalah perspektif yang paling penting dalam evaluasi kinerja organisasi publik, kemudian pembelajaran dan pertumbuhan dengan bobot prioritas 0,31889 . Serta analisis bobot prioritas indikator kinerja seperti yang ditunjukkan pada Tabel 7. Pengelolaaan asset dan pembiayaan yang optimal adalah indikator yang paling penting dengan bobot prioritas 0,10652 pada perspektif proses bisnis internal. Hal ini menunjukkan bahwa proses bisnis atau pekerjaan yang paling penting dari organisasi publik pada kantor pelayanan pajak adalah untuk melakukan pengelolaan aset dan proses pembiayaan secara akurat dan cepat.

Tabel 7. Nilai Bobot Akhir
Pengelolaan neraca pemerintah yang optimal adalah sasaran strategis yang menempati urutan kedua dengan bobot prioritas 0,0923 pada perspektif keuangan. Belanja dan transfer yang optimal merupakan sasaran strategis penting ketiga dengan bobot prioritas 0,0920 dan sasaran strategis organisasi yang kondusif diurutan keempat dengan bobot prioritas 0,0861. Meskipun perspektif keuangan dan pelanggan pada umumnya paling ditekankan oleh pihak manajemen namun dalam penelitian ini perspektif keuangan dan pelanggan berada pada peringkat yang sangat rendah diantara perspektif lain pada organisasi publik.

\begin{tabular}{cclc}
\hline Kriteria & Nilai Bobot & \multicolumn{1}{c}{ Subkriteria } & Nilai Bobot \\
\hline \multirow{2}{*}{ Keuangan } & \multirow{2}{*}{0,17597} & Pertumbuhan ekonomi yang inklusif & 0,08359 \\
& & Pengelolan neraca pemerintahan yang optimal & 0,09238 \\
Pelanggan & \multirow{2}{*}{0,15701} & Pemenuhan layanan publik & 0,08194 \\
& & Kepatuhan pengguna layanan yang tinggi & 0,07508 \\
& & Formulasi kebijakan fiskal yang berkualitas & 0,07877 \\
Proses Bisnis & \multirow{2}{*}{0,34812} & Belanja dan transfer yang optimal & 0,09205 \\
Internal & & Pengelolaan aset dan pembiayaan yang optimal & 0,10652 \\
& & Penegakan hukum yang efektif & 0,07078 \\
& & Sumber daya manusia yang kompetitif & 0,07302 \\
Pembelajaran dan & \multirow{2}{*}{0,31889} & Organisasi yang kondusif & 0,08616 \\
& & Sistem informasi manajemen yang terintegrasi & 0,07761 \\
& & Pelaksanaan anggaran yang optimal & 0,08211 \\
\hline
\end{tabular}

Hasil validasi siatem penilaian diberikan pada table 8. Dalam penelitian ini proses bisnis internal dengan bobot 0,34812 adalah perspektif yang paling penting dalam evaluasi kinerja organisasi publik dengan jumlah (34\%), selanjutnya pembelajaran dan pertumbuhan dengan bobot 0,31889 dengan jumlah $(31 \%)$, kemudian keuangan dengan bobot 0,17596 dengan jumlah (17\%) serta pelanggan dengan bobot prioritas 0,15701 dengan jumlah (15\%). Bobot global evaluasi kinerja ditunjukkan pada Gambar 7.

Tabel 8. Hasil validasi sistem penilaian

\begin{tabular}{lccc}
\multicolumn{1}{c}{ Perspektif } & $\begin{array}{c}\text { Nilai } \\
\text { Bobot }\end{array}$ & $\begin{array}{c}\text { Rangking } \\
\text { Manual }\end{array}$ & $\begin{array}{c}\text { Rangking } \\
\text { Sistem }\end{array}$ \\
\hline $\begin{array}{l}\text { Perspektif } \\
\text { Keuangan }\end{array}$ & 0,17597 & 3 & 3 \\
$\begin{array}{l}\text { Perspektif } \\
\text { Pelanggan }\end{array}$ & 0,15701 & 4 & 4 \\
$\begin{array}{l}\text { Perspektif Proses } \\
\text { Bisnis Internal }\end{array}$ & 0,34812 & 1 & 1 \\
$\begin{array}{l}\text { Perspektif } \\
\text { Pembelajaran } \\
\text { dan Pertumbuhan }\end{array}$ & 0,31889 & 2 & 2 \\
\hline
\end{tabular}

Dapat diartikan bahwa pada evaluasi kinerja organisasi publik lebih menitikberatkan pada usaha pencapaian perspektif proses bisnis internal. Meskipun perspektif keuangan dan pelanggan pada umumnya paling ditekankan oleh manajemen namun dalam penelitian ini perspektif keuangan dan pelanggan berada pada peringkat yang sangat rendah diantara perspektif lain pada organisasi publik

Untuk sasaran strategis pengelolaan aset dan pembiayaan yang optimal dengan bobot prioritas 0,1065 adalah sasaran strategis yang paling penting. Pengelolaan neraca pemerintah yang optimal adalah sasaran strategis yang menempati urutan kedua dengan bobot prioritas 0,0923. Belanja dan transfer yang optimal merupakan sasaran strategis penting ketiga dengan bobot prioritas 0,0920. Sasaran strategis organisasi yang kondusif diurutan keempat dengan bobot prioritas 0,0861 . Kemudian sasaran strategis pertumbuhan ekonomi yang inklusif diurutan kelima dengan bobot prioritas 0,0835 dan selanjutnya sampai dengan bobot kepentingan terkecil adalah sasaran strategis penegakan hukum yang efektif dengan bobot 0,0707. Bobot global sasaran strategis evaluasi kinerja ditunjukkan pada Tabel 7.

Hal ini menunjukkan perbaikan pada perspektif pelanggan dengan bobot prioritas 0,15701 merupakan hal yang paling ditekankan oleh organisasi. 
Sedangkan untuk indikator kinerja penegakan hukum yang efektif pada perspektif proses bisnis internal dengan bobot prioritas 0,07078 dan sumber daya manusia yang kompetitif pada perpektif pembelajaran dan pertumbuhan dengan bobot prioritas 0,07302 merupakan faktor yang paling penting untuk dilakukan perbaikan.

\section{Kesimpulan}

Hasil penelitian menunjukkan bahwa proses bisnis internal $(0,34812)$ dan pembelajaran dan pertumbuhan $(0,31889)$ memiliki bobot yang lebih tinggi. Hal ini menunjukkan proses bisnis serta pembelajaran dan pertumbuhan pegawai merupakan faktor penting yang harus ditekankan oleh organisasai publik. Sedangkan untuk indikator kinerja penegakan hukum yang efektif pada perspektif proses bisnis internal dengan bobot prioritas $(0,07078)$ dan sumber daya manusia yang kompetitif pada perpektif pembelajaran dan pertumbuhan dengan bobot prioritas $(0,07302)$ merupakan faktor yang paling penting untuk dilakukan perbaikan oleh organisasi publik.

Kajian peneliti sebelumnya dari literatur yang menggunakan metode Balanced Scorecard dan Analytic Network Process untuk penilaian evaluasi kinerja dapat diadopsi sebagai alat untuk memperkirakan bobot pentingnya sasaran strategis. Selanjutnya dengan menggunakan metode yang diusulkan untuk analisis evaluasi kinerja yang terkait dengan perusahaan manufaktur (Yuksel dan Dagdeviren, 2010).

\section{Daftar Pustaka}

Banker, R. D., Chang, H., Janakiraman, S. N., Konstans, C., 2004. A balanced scorecard analysis of performance metrics. European Journal of Operational Research, 154, 423-436.

Boj, J. J., Rodriguez, R., Alfaro Saiz, J. J., 2014. An ANP multicriteria based methodology to link intangible assets and organizational performance in a balanced scorecard context. Decision Support Systems, 68, 98-110.

Domanovi C, V., Jaksi C, M., Mimovi C, P., 2014. Balanced scorecard and analytic network process in performance measurement and strategy evaluation: a case study. TEME: Casopis $\mathrm{Za}$ Drutvene Nauke, 38(4), 1457-1474.

Gencer, C., Gürpinar, D. 2007. Analytic Network in Supplier Selection: A Case Study in an Electronic

Firm," Applied Mathematical Modelling, Vol 31, 11: 2475-2486.

Grigoroudis, E., Orfanoudaki, E., Zopounidis, C. 2012. Strategic performance measurement in a healthcare organisation: A multiple criteria approach based on balanced scorecard. Omega, 40(1), 104-119.
Kadarova, L., Michaela, D, A., Kalafusova L. 2014. a Innovative approaches to the modification of BSC model. Procedia Social and Behavioral Sciences, 143, 168-173

Leung, L. C., Lam, K. C., Cao, D. 2006. Implementing the balanced scorecard using the analytic hierarchy process and the analytic network process. Journal of the Operational Research Society, 57, 682-691.

Lupi, S., Verzola, A., Carandina, G., Salani, M., Antonioli, P., Gregorio, P., 2011. Multidimensional evaluation of performance with experimental application of balanced scorecard: A two year experience. Cost Effectiveness and Resource Allocation, 9, 7.

Perçin, S. 2008. Using the ANP approach in selecting and benchmarking ERP systems Benchmarking: An International Journal, Vol. 15, 5: 630 - 649

Ravi, V., Shankar, R., Tiwari, M. K., 2005. Analyzing alternatives in reverse logistics for end of life computers: ANP and balanced scorecard approach.

Computers and Industrial Engineering, 48, 327356.

Saaty, Thomas L., Vargas, Luis G., 2006. Decesion making with the Analytic Network Process. USA. Springer Science.

Tjader,Y, May, J. H, Shang, J, Vargas L, Gao, N., 2014. Firm level outsourcing decision making: A balanced scorecard based analytic network process model. Int. J. Production Economics 147, 614-623

Toosi, F. Z., Tabari, N. A. Y., 2014. Identifying and prioritizing the most important competitive factors in hotels based on balanced scorecard and ANP method. Indian Journal of Scientific Research, 4 (6), 855-860.

Wu, S.I., Hung, J.M., 2008. A performance evaluation model of CRM on nonprofit organizations. Total Quality Management and Business Excellence 19 (4), 321-342.

Yuksel, I., Dagdeviren M., 2010. Using the analytic network process (ANP) for Balanced Scorecard (BSC): a case study for a manufacturing firm. Expert Systems with Applications; 37:1270-8.

Zhang, I., Wang, C., 2011. Application of analytic network process in agricultural products logistics performance evaluation. Innovative Computing and Information volume 231 of the series communications in Computer and Information Science pp 500-506. 